\title{
CONSERVAÇÃO E PROTEÇÃO DO PATRIMÔNIO NA ARQUEOLOGIA HISTÓRICA: TIJOLOS DO RECIFE, PE, BRASIL ${ }^{1}$
}

Maria Aparecida da Silva

\section{Oliveira *}

Ana Catarina Peregrino

Torres Ramos**

Neuvânia Curty Ghetti**
* Mestre em Arqueologia pelo Programa de Pós-Graduação em Arqueologia da UFPE **Departamento de Arqueologia da UFPE.
RESUMO: Este artigo aborda a trajetória das intervenções de preservação voltadas aos bens culturais, suas primeiras ideias e teorias, assim como os princípios, métodos e técnicas da conservação e preservação do patrimônio cultural, verificados em diversos momentos da história. Teve por objetivo analisar explicar ações de conservação nos tijolos presentes na coleção arqueológica formada a partir desses vestígios encontrados nas escavações realizadas no bairro do Recife, na cidade do Recife, por arqueólogos da Universidade Federal de Pernambuco, com apoio do Programa Monumenta/BID, entre os anos de 2006 e 2007. Essas ações de conservação visaram a melhoria das condições de preservação desses tijolos, auxiliando a sistematizar e obter dados dos seus atributos, verificar a presença ou não de agentes degradantes e sugerir e realizar intervenções de acondicionamento para a sua preservação. A coleção possui 268 tijolos, com 47 íntegros e 221 fragmentos. Foram identificados tijolos íntegros em dois grupos: tijolos amarelos, predominantes (91,49\%) e com características de procedência holandesa, com menor diversidade de formas; e vermelhos, do centro do Recife, em menor número $(8,51 \%)$ e com maior diversidade de formas.

Palavras-chave: Tijolos, Programa Monumenta, Bairro do Recife, Arqueologia Histórica, Conservação Arqueológica.

ABSTRACT: This article addresses the trajectory of preservation interventions focused on cultural assets, their first ideas and theories, as well as the principles, methods and techniques of conservation and preservation of cultural heritage, verified at various times of History. It was intended to analyze and apply conservation actions on the bricks present in the archaeological collection formed from these traces found in the excavations carried out in the Recife district, in the city of Recife, by archaeologists from the Federal University of Pernambuco, with support from the Monumenta/IDB program, between the years 2006 and 2007. These conservation actions aimed at improving the conditions of preservation of these bricks by helping to systematize and obtain data of their attributes, to verify the presence or not of degrading agents and to suggest and perform packaging interventions for the your preservation. The collection has 268 bricks, with 47 intact and 221 fragments. Solid bricks were identified in two groups: yellow bricks, predominant $(91.49 \%)$ and with characteristics of Dutch origin, and reds, from the center of Recife, in lesser numbers (8.51\%) and with greater diversity of forms.

Keywords: Bricks, Monumenta program, Recife neighborhood, Historical archaeology, Archaeological conservation. 


\section{Conservação e proteção do patrimônio cultural.}

As intervenções de preservação voltadas aos bens culturais, sobretudo aos edificados, têm sido registradas desde a antiguidade. A partir da preocupação com as ações de restauro dos monumentos, desenvolveram-se as primeiras ideias sobre uma teoria que se tornou complexa e acabou se direcionando as edificações arquitetônicas ou bens imóveis. Conforme o implemento das tecnologias e como cada sociedade passou a ver a restauração, essa teoria tornou-se dinâmica, desenvolvendo novos critérios e metodologias.

Os princípios, métodos e técnicas da conservação e preservação do patrimônio cultural (dos bens de propriedades imóveis, objetos de arte e outros) podem ser verificados em diversos momentos da história da humanidade (Velosa, 2008). Foi somente após a II Guerra Mundial, que se firmaram os elementos regulamentadores da conservação preventiva do patrimônio cultural. Participaram desse processo os preceitos da Carta de Atenas, de 1931, Carta de Veneza, de 1964 e Carta da Itália, de 1987 (Cury, 2004). A conservação, prevenção, salvaguarda, manutenção e restauração relacionam-se de forma complementar (Caldeira, 2005/2006).

Conforme Vasconcelos (2011), no Brasil, os instrumentos legais de proteção de monumentos arqueológicos e pré-históricos incluem a Lei Federal $n^{\circ} 3.924$, de 26/07/1961, a primeira a tratar sobre esse tipo de patrimônio; a Portaria $n^{\circ} 07$ (Sphan), de 1/12/1988, cujo artigo 11 trata da obrigação do arqueólogo quanto às medidas de conservação dos materiais arqueológicos; a Portaria $\mathrm{n}^{\circ} 230$ (Iphan), de 17/12/2002, nos parágrafos 6 e 7, referentes à adequação do acondicionamento dos materiais coletados em campo e no laboratório.

Também estão incluídas as prerrogativas de identificação sistemática dos sítios arqueológicos, entre outras práticas. Esses instrumentos legais trazem indicações sobre a necessidade de conservação dos materiais arqueológicos, mesmo diante de acondicionamentos em reservas técnicas inadequadas e não compromissadas com a conservação preventiva, desinformação sobre políticas de preservação de acervos, falta de técnicos especializados e documentação arqueológica não organizada (Vasconcelos, 2011).

A formulação de protocolos de conservação e manejo de acervos arqueológicos demanda relações interdisciplinares e já tem sido parte da demanda exigida as instituições científicas que guardam acervos arqueológicos no Brasil. A ampliação da conservação preventiva relaciona-se diretamente com acervos em Reserva Técnica (RT). Esse processo ocorre em conjunto com a necessidade de guias práticos de diagnóstico e avaliação de edificações, monumentos e coleções para elaborar estratégias (prognósticos) voltadas à redução dos riscos potenciais de degradação de acervos arqueológicos; e auxílio no gerenciamento e controle do patrimônio arqueológico (Froner, 1995; Hirata e Froner, 1997; Froner, 2005; Leal, 2014).

Sob a perspectiva da caracterização das práticas de Conservação, Restauro e Salvaguarda do patrimônio arqueológico, voltada aos bens móveis - materiais arqueológicos - e imóveis, torna-se importante a adequação de procedimentos propostos por Cronyn (1990), Hirata e Froner (1997), Ghetti (2009, 2013, 2014), Ghetti e Najjar (2009),Mendes (2001), Vasconcelos (2011) e Leal (2014). 
Entretanto, a formação inicial de uma teoria sobre a restauração do patrimônio verifica-se em meados do séc. XIX, com a publicação de pelo menos três obras importantes: as de John Ruskin (1849), Viollet-le-Duc (1872) e Camillo Boito (1884), nas edições de 1989, 2000 e 2003, respectivamente. Esses autores enfocavam especialmente os bens patrimoniais imóveis. A ideia de conservação do inglês John Ruskin (1819-1900) não significava restauração. O ideal em Ruskin era que os monumentos fossem bem cuidados para que não precisassem de restauros. Para ele, conservar ou destruir monumentos antigos não era dever dos seus contemporâneos, mas das gerações futuras. Uma ruína ou edificação em abandono constituísse em cena pictórica, um lugar da memória para a transmissão para o futuro do trabalho dos antepassados. Interessava a ele a idade de um monumento, o monumentorelíquia, sempre original, não restaurável. Fundou a Society for theProtection of Ancient Building, voltada à preservação do passado medieval (Tinoco, 2015).

Os primeiros restauradores surgem na França, durante a atuação de LudovicVitet e Prospére Mérimeé na Comissão de Monumentos Históricos. Nesse contexto destacou-se o arquiteto e crítico Eugene Emmanuel Viollet-le-Duc, fundamentado no historicismo, que sistematizou a disciplina da restauração de monumentos históricos. Uma ruína - como várias encontradas no subsolo do Bairro do Recife durante o Programa Monumenta, realizado no ano de 2006 - era considerada como um elemento histórico-arquitetônico, onde o passado deveria ser interpretado, reestabelecido e valorizado. Os edifícios arruinados ou inacabados deveriam ser restituídos pelo restaurador até alcançarem a integridade artística perfeita. A restauração era uma ciência e uma arte, contando com a inspiração e habilidade do restaurador, sendo sempre retirada toda a estratificação histórica sobreposta ao monumento restaurado. Um edifício é restaurado não quando é mantido, reparado ou refeito, mas quando é restabelecido em um estado completo que pode não ter existido nunca em um dado momento (Lira, 2015).

Diferentemente de Viollet-le-Duc (2000), o italiano Camilo Boito (2003), considerava o monumento histórico como um documento de arte e de história, devendo ser conservadas todas as suas estratificações que não prejudicassem as suas partes mais notáveis (Tinoco, 2015). Para Boito (2003) e Ruskin (1989), uma ruína não deveria ser reconstruída, mas conservada por meio da consolidação com materiais distintos dos originais. Os conceitos de Boito (2003) referiam-se às complementações e aos acréscimos que deveriam ser feitos nas construções, seguindo documentos históricos antigos sobre a forma das edificações que sofreriam complementações ou acréscimos e o emprego de estilo neutro, nos casos de falta de informação suficiente sobre a ruína em processo de conservação.

A Conferência Internacional de Atenas de 1931 fez uso de um princípio de Camilo Boito (2003): a necessidade de uma constante obra de manutenção e consolidação de monumentos antigos deve estar apoiada no uso de meios técnicos e sistemas construtivos mais modernos. Boito aceitava que os monumentos antigos constituíam documentos da história dos povos e deveriam ser respeitados. Também deveriam ser consolidados e não reparados, ou antes reparados, do que restaurados, sempre evitando as adições e renovações. Caso já tenham sido praticadas em tempos mais antigos no monumento, estas deveriam ser mantidas, como partes do mesmo (Tinoco, 2015). 
Ainda, para Boito (2003), mesmo tratando da escultura, da pintura e da arquitetura, concebe a conservação como relativa à tomada de providências imprescindíveis para a sobrevivência de um bem e a restauração como algo oposto, mas necessário. No caso dos bens arquitetônicos, estes devem sofrer intervenções de restauro para conservar o seu velho aspecto artístico e pitoresco e que as adições e complementos (réplicas) necessários devem ser recentes e diferentes do restante do monumento, mais antigo. Aceitava os preceitos da anastilose e do restauro filológico, preservando o valor documental da obra (Lira, 2015).

As noções de tempo, espaço, valor e patrimônio estão intrinsecamente relacionados. Para compreender a noção de patrimônio, este se relaciona com um referencial antrópico necessário para o desenvolvimento das relações sociais, para auxiliar na compreensão da mudança de forma linear, contínua e ininterrupta - o tempo; com um conjunto de formas, territórios e ações, processos, materialidades e sociedades, de caráter tridimensional - o espaço; e com outra construção humana fundada em consensos e acordos, histórica e que dá sentido ao tempo e ao espaço - o valor (Tinoco, 2015).

A própria noção de patrimônio, nessa relação, aparece diante da valoração dada aos bens pelo homem em determinado tempo e espaço. O patrimônio possui vários significados culturais, com valores estéticos, científicos, históricos, sociais, espirituais, conforme cada sociedade, conforme a Carta de Burra, de 1980. Toda conservação do patrimônio cultural, na sua diversidade de formas e períodos, fundamenta-se nos valores a ele atribuídos, mediante a Carta de Nara, de 1994. Estas cartas patrimoniais estão compiladas em Cury (2004).

Os textos de Ruskin (1989), Viollet-le-Duc (2000) e Boito (2003) serviram para a elaboração das obras de Aloïs Riegl (1999) e a de Cesare Brandi (2003), importantes marcos da construção da teoria da restauração moderna. Somente a partir do séc. XX estrutura-se um corpo teórico mais consolidado, especialmente nas obras de Riegl (1999) e Brandi (2003). Em 1903, Riegl publica o seu $O$ Culto Moderno aos Monumentos. No texto, o autor procurou organizar os conceitos relativos ao processo da conservação dos monumentos e aos valores dos mesmos. Ele sistematizou as perspectivas de Ruskin, Viollet-le-Duc e Boito, enfocando a identificação e a categorização dos valores atribuídos aos monumentos (Lira, 2015) os sítios arqueológicos estão inseridos em ambientes naturais que representam recursos finitos e não substituíveis, cuja deterioração segue por um percurso próprio (Matero, 2015) ${ }^{2}$. Com a investigação científica e o estudo de muitos sítios arqueológicos realizados no final do séc. XIX, tanto os valores estéticos quanto informativos foram criados durante a escavação-estabilização dos mesmos. Na prática contemporânea, as opções pela conservação dos sítios arqueológicos têm incluído a reconstrução, remontagem (ou anastilose), preservação in situ e proteção com abrigos ou lonas.

Para Matero (2015), os arqueólogos, conservadores e os profissionais ligados ao patrimônio cultural devem se familiarizar com as questões políticas, econômicas e culturais da gestão de

\footnotetext{
2 Frank G. Matero é professor de arquitetura do Programa de Graduação em Preservação Histórica e diretor do Architectural Conservation Laboratory da University of Pennsylvania. Foi diretor do Center for Preservation Research da Columbia University (1981-1990) e palestrante do International Center for the Study of the Preservation and the Restoration of Cultural Property em Roma (UNESCO-ICCROM) e da Universidade Politécnica de Porto Rico (Matero, 2015).
} 
recursos e as aplicações do seu trabalho para as comunidades locais, inclusive questões de apropriação de tecnologia, tradição e sustentabilidade.

O status dos bens culturais vem sofrendo mudanças ao longo do tempo e nas diversas sociedades. Vinculado à palavra latina documentum, derivado de docere (ensinar) evoluiu, segundo Le Goff (1982) para o sentido de "prova", testemunho escrito que retira dos objetos e das construções as suas forças discursivas, recuperadas pela palavra latina monumentum, que representa uma das funções do mens (espírito), denominado de memini (memória). Interessava o monere, ou fazer recordar, iluminar, instruir. Para o historiador francês, monumentatun é um sinal do passado. Assim, pelas origens filológicas, monumento é tudo aquilo que pode evocar o passado, perpetuar a recordação. Essa definição filológica de monumento foi recuperada por Froner (2007).

Os conceitos de Aloïs Riegl (1999), escritos em 1903, circunscritos à História e à Filosofia da Arte, foram utilizados como base para a prática profissional, incluindo o respeito aos originais antigos e aos critérios de seleção a partir da noção de valor (Froner, 2007). Esse pensador foi importante por ter reunido duas tradições do final do séc. XIX; a dos museus e das universidades, buscando a análise metódica dos objetos que estavam sob a sua guarda e a estruturação dos seus estudos. Os objetos existem enquanto elementos a serem preservados, sempre quando Ihes são atribuídos, antropicamente, valores axiomáticos como o cultural, artístico e histórico, tomando parte na rede das trocas simbólicas. Os valores são do culto, da singularidade artística ou exótica, patrimonial, com sentido histórico agregado (Froner, 2007).

Somente a partir do séc. XIX, segundo Froner (2007), com a difusão de museus no modelo francês, surgiram administradores especialistas que determinam as novas posturas dos restauradores em relação às coleções advindas de diferentes empreitadas dos Estados Nacionais. São adotados critérios científicos advindos da Física, Química, Geologia e Biologia na lida com os artefatos antigos e obras de arte, modificando as posturas dos restauradores.

Riegl (1999) já alertava para a necessidade inevitável da presença do profissional conservador/restaurador conhecedor de História e História da Arte, especialmente, para minimizar erros e ações danosas à qualidade estética ou documental dos monumentos cultuados. Morris (1996) e Ruskin (1989) não aceitavam as complementações estruturais e as construções adjacentes aos edifícios antigos. A vertente dos puristas, com representante em Boito (2003), questionou os métodos e estabeleceu princípios em relação à prática da restauração: à prática indiscriminada das reconstruções e preenchimentos e a colocação de ferraduras nos cavalos de estátuas romanas e gregas (Froner, 2007). Durante o Renascimento e o Barroco, como lembra Tinoco (2015) e Froner (2007), não era imoral criar e trabalhar sobre obras de arte da antiguidade. Foi somente na segunda metade do séc. XIX que a restauração surge como uma intervenção técnico-científica e não mais somente como uma experiência artística. Associam-se à Ciência da Conservação a Arqueologia, Arquitetura e a História da Arte, que adquirem um corpo conceitual nesse período histórico na Europa.

Somente após a Primeira Grande Guerra, os princípios científicos até então validados da restauração foram tratados, em 1930, pelo Escritório Internacional de Museus da Liga das Nações, na Europa, diante da quantidade de destroços produzida e das restaurações 
indiscriminadas. Segundo Froner (2007) é, então, utilizada a expressão "método científico" sobre o ofício da restauração. Surge a noção de patrimônio mundial e o patrimônio cultural é concebido como possuidor de existência histórica e social ampla. Destacaram-se Gustavo Giovannoni, que influenciou em 1931 a Carta de Atenas (Cury, 2004), e Giovanni Carbonara (Froner, 2007).

O uso da Química e da Física surgem nos anos 1960, aplicados não no nível industrial, mas em cada obra, por sua unicidade e especificidade. As fórmulas químicas não funcionam como receitas pré-estabelecidas, pois irão depender de cada caso em estudo: cada bem cultural apresenta especificidades que demandam experiências diversas e novas, não restritas aos métodos e técnicas cotidianos de físicos e químicos (Froner, 2007).

Após a década de 1980, a salvaguarda do patrimônio passou a sustentar as ações de preservação dos acervos. A Arqueologia inicia o debate sobre as intervenções de restauro e as medidas preventivas de conservação dos bens recuperados durante as escavações arqueológicas. Esse debate se dá na França, onde os conservadores passam a acompanhar os trabalhos de campo até as etapas laboratoriais e de finalização da pesquisa. Para Berducou (1990, p. 419 apud Froner, 2007, p. 16), os arqueólogos nesse meio possuíam a tendência de apreender um objeto do ponto de vista cronológico - o problema do tempo - morfológico, técnico e funcional, enquanto que o restaurador apreendia os objetos sob o ponto de vista material e técnico.

Atualmente, segundo Froner (2007), definições mais precisas e particulares das classificações: "conservação", "restauração" e "preservação" se encontram em desenvolvimento. Segundo esta pesquisadora, a conservação preventiva está sendo priorizada visando proteger a integridade dos objetos, reduzindo a importância das técnicas interventivas diretas.

A Conservação preventiva - como base normativa da Ciência da Conservação - de bens patrimoniais culturais de natureza móvel e imóvel envolve a compreensão das propriedades dos materiais, o macro e microambientes, o estado da preservação e os processos de deterioração, o desenvolvimento de materiais e de métodos de conservação, passando a uma área de saber específica, com a participação efetiva das ciências naturais, valorizando e interpretando o patrimônio cultural Articula, segundo Froner (2007), as teorias das ciências exatas e humanas e demanda uma consciência pública sobre a sua necessidade.

Os projetos de arqueologia, quer prospectivos, avaliando o potencial arqueológico do bem, quer de pesquisas, aprofundando os trabalhos realizados no projeto de prospecções, devem contemplar algumas informações básicas, quando ordenados pela arqueologia histórica, entre elas as pesquisas sobre as tipologias e técnicas construtivas presentes na construção (Najjar, Duarte, 2002).

Obras de revitalização ${ }^{3}$ urbana e as intervenções arqueológicas (acompanhamentos) em avenidas e ruas podem resultar na exposição de pisos, fundações e em partes de paredes.

3 Revitalização tem sido um conceito que pode representar, por um lado, tanto a melhoria das condições sociais, econômicas, patrimoniais e ambientais de um meio urbano, fundado sob uma égide política, quanto por outro, como a desestruturação de 
Nesse caso, são significativos os procedimentos de campo recomendados por Najjar e Duarte (2002) e França e Brandão Filho (2014). Abordagens arqueológicas in situ, integradas, são relativamente comuns por parte de arqueólogos de formação em Arquitetura, como o caso de Matos (2009).

Na dissertação de Oliveira (2017) buscou-se - a partir do estudo extra situ dos tijolos recuperados no centro da cidade do Recife, durante as ações do Programa Monumenta - uma integração entre arqueologia, restauro e conservação, sob o viés da arqueologia histórica. Priorizou-se o diagnóstico, as características do estado de preservação e a sugestão de técnicas da arqueologia e de conservação investigativa integradas em amostras de materiais construtivos - os tijolos - provenientes das áreas escavadas durante o Projeto Processo de Urbanização do Bairro do Recife entre os séculos XVII e XVIII (Programa Monumenta - Recife, 2006). Este exemplo considera a diversidade, estado de conservação, preservação, documentação e potencial de análise e interpretação dessa categoria de material arqueológico, encontrado peculiarmente em sítios arqueológicos urbanos e a sua disponibilidade nas novas RT dos Laboratórios de Arqueologia da UFPE.

A partir da sua documentação e registro de guarda, tornou-se possível obter uma listagem de tipologias e proveniências de um conjunto de amostras de materiais de tipos diversos, como os artefatos, provenientes do Polo da Alfândega e representativos de áreas de descarte e aterro no núcleo residencial e comercial do Bairro do Recife, entre os séculos XVII e XVIII, passíveis de um estudo de revisão, com ênfase nos métodos e técnicas da arqueologia aplicada em laboratório, integrados à conservação e restauro investigativos. As intervenções arqueológicas no Polo da Alfândega/Madre de Deus estavam previstas no Programa Monumenta/BID /Fumdham/ PPGA4 -UFPE e Prefeitura da cidade do Recife:

O Polo Alfândega/Madre de Deus, que faz parte de iniciativas municipais de revitalização do Bairro do Recife desde 1987, é constituído de edificações de grande valor arquitetônico, histórico e cultural, abrigando parte do Núcleo Original da Cidade do Recife, tombado pelo IPHAN. O inegável valor do seu acervo, notadamente pela presença da Igreja da Madre de Deus, monumento tombado, tornou o Polo alvo dos investimentos do Programa Monumenta/BID a partir do ano 2000 (PESSIS et al., 2006, p. 3).

As participações da Fundação Museu do Homem Americano (Fumdham) e do Programa de Pós-Graduação de Arqueologia foram fundamentais para o bom andamento do Projeto Processo de urbanização do Bairro do Recife nos séculos XVII e XVIII. Em um contexto mais amplo, o Programa Monumenta representou um programa oficial de preservação urbana e salvaguarda das cidades históricas brasileiras, desenvolvido pelo Governo Federal e o Banco Interamericano de Desenvolvimento (BID), em conjunto com parcerias privadas e públicas no Brasil (Duarte Junior, 2010). Nas regiões norte, nordeste e centro-oeste os sítios históricos e

condições sociais, econômicas e patrimoniais preexistentes em detrimento de uma nova condição urbana, também amparada por demandas políticas. Outros tipos de demandas podem gerar obras de revitalização nos centros urbanos, relacionadas à melhoria do tráfego, conservação e restauro de bens imóveis históricos e a transferência de grupos humanos em situação de extrema degradação social, cultural e econômica, por motivos ideológicos, políticos, eugênicos, econômicos e higienistas (OLIVEIRA, 2017).

4 Programa de Pós-Graduação em Arqueologia da UFPE. 
conjuntos urbanos de monumentos nacionais foram relacionados nos Sítios Históricos e Conjuntos Urbanos de Monumentos Nacionais (Brasil, 2005).

Em termos de ocupação urbana, após a saída dos holandeses - quando houve um elevado índice demográfico em um reduzido espaço de ocupação - a Vila do Recife passou por remodelações que se seguiram até 1910 , com a sua máxima ampliação, resultante de materiais de descarte e aterros sucessivos. Esses vestígios foram recuperados durante 0 acompanhamento do Plano de Trabalho da URB-Recife, que realizou obras de urbanização, pelo Projeto citado. Foram acompanhadas as obras na Rua da Moeda, trecho da Av. Alfredo Lisboa, Ruas Madre de Deus; Vigário Tenório; da Alfândega; Aluísio Magalhães e Aluízio Periquito, localizadas no perímetro citado e dentre os recursos humanos da URB- Recife e da 5a्CR do Iphan (Pessis et al., 2006).

Ao Projeto cabia reconstruir o traçado urbano no Polo da Alfândega, Bairro do Recife, entre os séculos XVII e XVIII e a memória colonial dessa paisagem, a partir da identificação de estruturas remanescentes do planejamento urbano. Foram afetados os bens imóveis e recuperados materiais arqueológicos com complexidades estruturais e funcionais distintas. Constituíam objetivos específicos do projeto arqueológico realizado no Bairro do Recife: a) identificar as técnicas construtivas dos séculos XVII e XVIII; b) identificar atividades do cotidiano daquelas épocas através da cultura material; c) identificar o processo de formação geológica do sítio e as alterações ocorridas naquele período. Nesta pesquisa foi realizado um trabalho de recuperação de dados tipológicos, avaliação do estado de preservação, sugestão de parâmetros de preservação e foram formuladas hipóteses sobre a dinâmica dos usos, reutilizações e descartes dos tijolos no contexto arqueológico urbano do Recife, com vistas a contribuir com o objetivo a) do referido projeto.

Outros processos de intervenção arqueológica já haviam sido realizados antes de 2006 no Bairro do Recife, durante as suas várias reformas e reutilização de estruturas arquitetônicas (Rufino, 2013). Entre elas, Pessis et al (2006), destaca a identificação da estrutura em cantaria da Porta da Terra, o Baluarte; a estrutura do Forte do Bom Jesus; o dique em pedra de cantaria, no Museu a céu Aberto, bem como galerias de águas fluviais em arcos na Avenida Alfredo Lisboa e a escavação da Cruz do Patrão.

A região abrangida pelo Projeto Monumenta, no centro da cidade do Recife, apresenta aspectos arqueológicos, históricos e arquitetônicos importantes e peculiares que contribuem, de forma significativa, para o conhecimento sobre o povoamento e a história da formação urbana da região litorânea de Pernambuco, assim como sobre o potencial de análise, interpretação arqueológica, conservação e restauro dos materiais arqueológicos construtivos retirados do contexto do patrimônio edificado. Este contexto patrimonial, tanto na cota positiva, quanto na negativa (subsolo), encontra-se em constante remodelação decorrente do processo de desenvolvimento urbano e todas as suas consequências. O levantamento e estudo dos vestígios arqueológicos históricos - o material construtivo tijolo - mantidos em RT na UFPE, tem valor relevante, especialmente em face da carência de trabalhos de investigação nessa temática específica da integração direta da arqueologia com a conservação e restauro. 
O contexto arqueológico de onde provêm os remanescentes das escavações nas ruas do centro do Recife, conforme o Programa Monumenta, não pode mais ser revisitado no contexto do subsolo, conquanto somente pela consulta aos cadernos, mapas, relatórios e documentação gráfica e fotográfica de campo e laboratório, somados às publicações subsequentes. Entretanto, os materiais arqueológicos, de naturezas diversas, sob a forma de amostras, podem ser revisitados na RT do Departamento de Arqueologia da UFPE (Retec-Arq). O cuidado está na forma de abordagem - que deve ser integrada entre a arqueologia e a conservação e restauro.

Sob este aspecto, no caso específico dos produtos cerâmicos recuperados de sítios arqueológicos, mudanças após a retirada de campo podem incluir novas condições mecânicas, físicas, contaminações químicas e biológicas, assim como situações de risco (Moliner, 2009). Como os produtos cerâmicos constituem materiais inorgânicos, que depois do cozimento adquirem condições físicas de durabilidade que os tornam imprescindíveis em vários âmbitos da vida cotidiana das sociedades, comumente representam vestígios de caráter mais resistentes. Entretanto, alguns fatores podem causar a sua deterioração. $O$ primeiro grupo de fatores, segundo Moliner (2009), está representado pelas alterações provocadas pelo homem (furtos, tratamentos inadequados de conservação e restauração, manipulação inadequada, atividades agrícolas e de construção). O segundo grupo inclui os fatores ambientais (desequilíbrios entre os produtos cerâmicos e o meio no qual estão inseridos). De acordo com Moliner, para o restaurador de arqueologia, no caso dos produtos cerâmicos, deve proceder sob duas perspectivas: "1) na conservação, consistindo em desacelerar ao máximo os processos de degradação, diminuindo assim, os desequilíbrios instalados entre o objeto e o novo meio ambiente pós-escavação; 2) na restauração, pela qual serão reparados os danos já ocasionados, ampliando desse modo a eficácia dos tratamentos de conservação" (Moliner, 2009, p. 44).

Sobre os agentes degradadores de tijolos e pedras, as classificações de Almeida (2000) e Moliner (2009) podem ser adaptadas: tanto tijolos quanto pedras sofrem estresses externos e internos, a ação de agentes físicos externos, ataques biológicos, demandando uma identificação das patologias para direcionar projetos de restauro ou de conservação. Os agentes degradadores de rochas e produtos cerâmicos estão resumidos no Quadro 1:

Quadro 1. Agentes degradadores dos produtos cerâmicos e rochas. Fonte: adaptado de Almeida (2000) e Moliner (2009).

\begin{tabular}{|c|c|c|c|}
\hline Agentes & Causas & Elementos & Danos \\
\hline \multirow{4}{*}{ Estresses externos } & Carga & $\begin{array}{l}\text { Colunas, pilares, vigas, cantarias, } \\
\text { parede, piso, poço, fundação de } \\
\text { alvenaria }\end{array}$ & Deformação, microfissuras \\
\hline & $\begin{array}{l}\text { Expansão } \\
\text { térmica }\end{array}$ & $\begin{array}{l}\text { Cantarias, paredes, pisos, } \\
\text { alvenarias, pilares, vigas, poços }\end{array}$ & $\begin{array}{l}\text { Microfissuras, deformação, fraturas, } \\
\text { descascamento }\end{array}$ \\
\hline & $\begin{array}{l}\text { Expansão pela } \\
\text { umidade }\end{array}$ & $\begin{array}{l}\text { Cantarias, paredes, pisos, } \\
\text { alvenarias, pilares, vigas, poços, } \\
\text { fundações }\end{array}$ & $\begin{array}{l}\text { Remodelação interna e superficial, } \\
\text { desagregação por dilatação } \\
\text { volumétrica e linear }\end{array}$ \\
\hline & Vibrações & $\begin{array}{l}\text { Tráfego, transportes, } \\
\text { manipulações, terremotos }\end{array}$ & $\begin{array}{lr}\begin{array}{l}\text { Fissuras, rupturas, } \\
\text { desagregação, }\end{array} & \begin{array}{r}\text { perdas, } \\
\text { esfoliação, }\end{array} \\
\text { craquelação, laminação } & \\
\end{array}$ \\
\hline
\end{tabular}




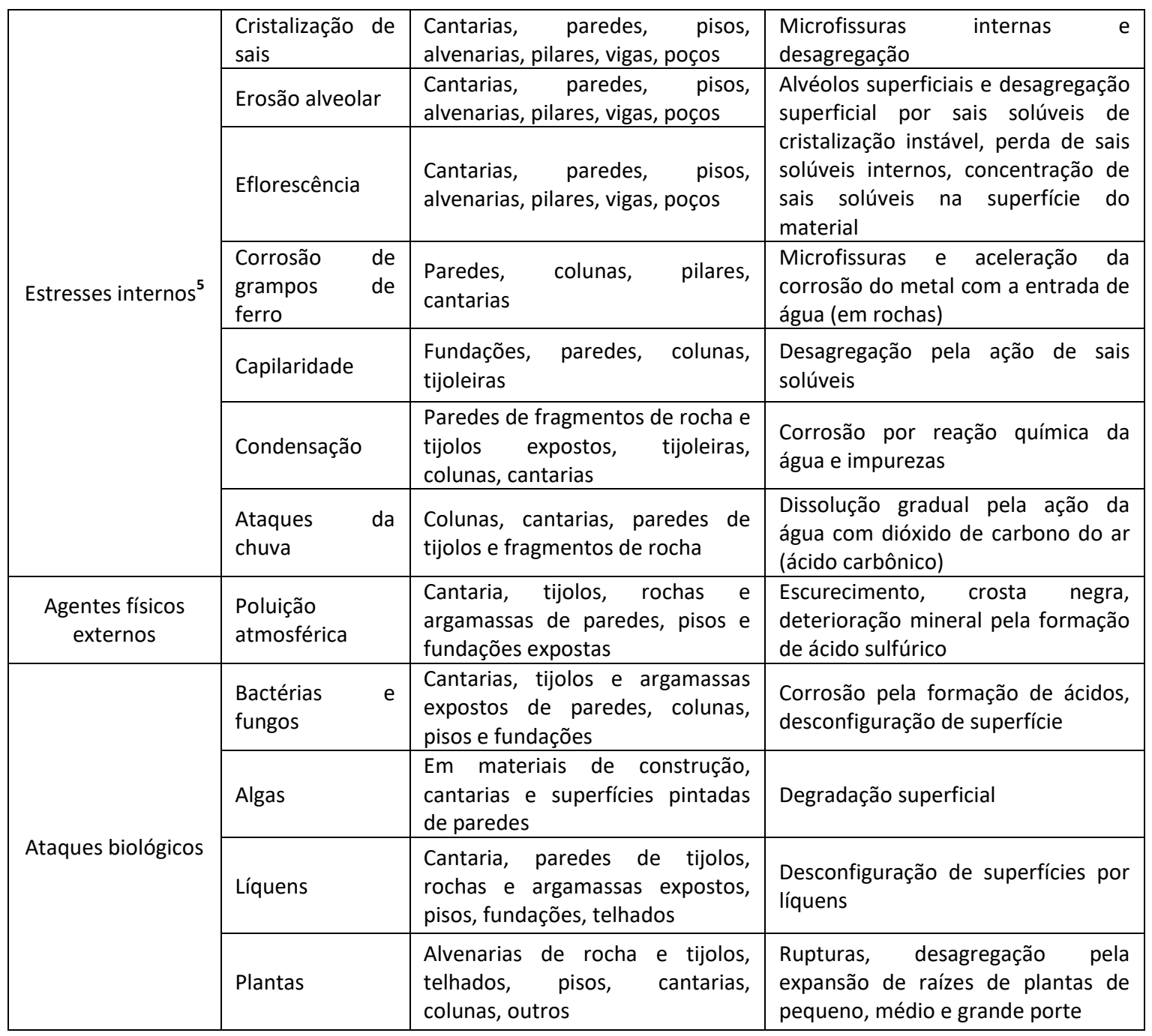

Para reconhecer as patologias que resultam dos danos causados pelos agentes de degradação dos produtos cerâmicos e pedras, Almeida (2000) sugeriu a seguinte classificação (Quadro 2), adaptada: 
Quadro 2. Reconhecimento de patologias em produtos cerâmicos e rochas em monumentos históricos.

\begin{tabular}{|c|c|}
\hline Patologia & Características \\
\hline Alteração cromática & $\begin{array}{l}\text { Reação superficial pelo escurecimento ou clareamento, podendo modificar a } \\
\text { cor original do material }\end{array}$ \\
\hline Alveolização & Formação de cavidades superficiais, com dimensões variadas \\
\hline Crosta negra & $\begin{array}{l}\text { Depósito de impurezas ambientais que reagem com o material, resultando } \\
\text { na sua degradação }\end{array}$ \\
\hline $\begin{array}{l}\text { Degradação } \\
\text { diferenciada }\end{array}$ & $\begin{array}{l}\text { Remodelação degradativa profunda devido à homogeneidade do material, } \\
\text { modificando a textura original }\end{array}$ \\
\hline Desagregação & Perda de coesão do material (rochas lapidadas, p. ex.) \\
\hline Esfoliação & Destacamento espesso de uma ou mais camadas do substrato superficial \\
\hline Fissura & $\begin{array}{l}\text { Áreas de descontinuidade do material, com o aparecimento de fendas ou } \\
\text { fraturas incompletas }\end{array}$ \\
\hline Perdas & $\begin{array}{l}\text { Formação de lacunas ou ausências no material por perda dos seus } \\
\text { componentes naquela área }\end{array}$ \\
\hline Pitting & $\begin{array}{l}\text { Degradação puntiforme com aparecimento de numerosos orifícios de } \\
\text { pequeno diâmetro }\end{array}$ \\
\hline $\begin{array}{l}\text { Presença de } \\
\text { vegetação }\end{array}$ & Impregnação de musgo, lodo ou plantas na superfície do material \\
\hline Grafitismo & $\begin{array}{l}\text { Presença de camada de tinta sobre a superfície de cantaria, tijolo ou } \\
\text { superfície de acabamento por depredação ou intervenção inadequada }\end{array}$ \\
\hline
\end{tabular}

Fonte: Adaptado de Almeida (2000).

Mais especificamente para o estudo dos tijolos arqueológicos, Vogel (2015) propõe a identificação de danos específicos (Quadro 3), como os definidos abaixo:

Quadro 3. Danos encontrados nos tijolos arqueológicos (Vogel, 2015)

\begin{tabular}{|c|c|}
\hline Tipo de dano & Causa, efeitos, tratamentos \\
\hline $\begin{array}{l}\text { Vitrificação, deformação, } \\
\text { escurecimento }\end{array}$ & $\begin{array}{l}\text { Ação de fogo durante incêndios em edificações. Não há tratamento. } \\
\text { Entretanto, é um importante indicador de acontecimentos históricos. }\end{array}$ \\
\hline $\begin{array}{l}\text { Eflorescência ou } \\
\text { concreção de sais }\end{array}$ & $\begin{array}{l}\text { Dano causado em escala de tempo lento. Ocorre mudança estética, } \\
\text { mas não estrutural. Trata-se de dano resultante da lixiviação } \\
\text { relacionada com a umidade nos sais na argila queimada, nos tijolos } \\
\text { inseridos na estrutura do edifício. Esses sais higroscópicos podem ser } \\
\text { removidos dos tijolos com uso de cataplasma de argila na área } \\
\text { manchada. Em RT convém reduzir a umidade crítica abaixo dos níveis } \\
\text { onde os sais aparecem, de modo que reações químicas possam ser } \\
\text { usadas para converter sais solúveis em sais insolúveis - dentro da } \\
\text { construção. Nesse caso, a aplicação de hidróxido de bário para } \\
\text { converter sulfato de sódio em sulfato de bário insolúvel. }\end{array}$ \\
\hline
\end{tabular}




\begin{tabular}{|l|l|}
\hline $\begin{array}{l}\text { Decomposição por } \\
\text { erosão }^{6}\end{array}$ & $\begin{array}{l}\text { Esse dano aparece visível em tijolos expostos às intempéries, com } \\
\text { características especificas de queima (baixa) ou expostos à ação das } \\
\text { águas durante as marés ou em áreas de correntezas com inundações } \\
\text { consecutivas. A ação eólica e de fitoturbação também podem } \\
\text { decompor os tijolos não refratários com maior rapidez. }\end{array}$ \\
\hline
\end{tabular}

Os métodos de tratamento de conservação dos produtos cerâmicos e das rochas dependem do estado de conservação no qual se encontrem. Os materiais de conservação usados devem ser anteriormente testados em amostras por profissionais. O método a ser usado está relacionado à natureza dos agentes impregnantes (sujidades) a serem removidos e do tipo e estado da superfície a ser higienizada ou limpa. Almeida (2000) estabeleceu algumas das seguintes operações de tratamento (Quadro 4) in situ ou em laboratório:

Quadro 4. Métodos de tratamento dos produtos cerâmicos e rochas de monumentos históricos.

Métodos não exclusivos de tratamento de produtos cerâmicos e rochasde monumentos históricos in situ ou em laboratório

\begin{tabular}{|c|c|}
\hline Operação & Procedimentos \\
\hline $\begin{array}{l}\text { Tratamento de } \\
\text { intervenções } \\
\text { anteriores }\end{array}$ & $\begin{array}{l}\text { Muitas intervenções produzidas por gerações anteriores nos produtos } \\
\text { cerâmicos de reservas técnicas e museus não possuíam a preocupação com a } \\
\text { reversibilidade dos materiais empregados ou preocupações estéticas, gerando } \\
\text { ou causando frequentes danos aos objetos cerâmicos. Essas antigas } \\
\text { intervenções devem ser documentadas, pois fazem parte da história do } \\
\text { artefato cerâmico, bem como as suas antigas fichas e etiquetas. }\end{array}$ \\
\hline Limpeza & $\begin{array}{l}\text { Remoção por ações químicas e físicas das substâncias que estejam causando } \\
\text { a deterioração (como sais solúveis, incrustações insolúveis, restos de } \\
\text { intervenções anteriores ineficazes, infestação de vegetação, exceções de } \\
\text { animais), respeitando a coloração e textura originais e de acordo com o tipo } \\
\text { de sujidade existente. Testes de eficiência do método devem ser feitos. } \\
\text { Convém que seja feita em superfícies que não apresentem destruição da } \\
\text { coesão das partículas do material. Em laboratório, esse procedimento é } \\
\text { muito delicado e deve estar baseado no conhecimento do material - } \\
\text { características da sua composição e ambiente - e na consciência da } \\
\text { irreversibilidade de alguns tipos de limpeza. } \\
\text { Limpeza com água: a água pode ser aplicada com vaporizador para evitar } \\
\text { umidificação intensa do material; com jateamento de água de baixa pressão } \\
\text { (máximo } 2,5 \text { a } 3 \text { atm.); podem ser aplicados em conjunto com escovas } \\
\text { acrílicas, exceto em superfícies de rochas e tijolos muito porosas. } \\
\text { Limpeza química: uso de pastas aquosas de argilas absorventes como } \\
\text { sepiolita ou betonita, polpa de papel, polpa de algodão, sílica gel como } \\
\text { suportes para a aplicação de substâncias químicas previamente testadas; uso } \\
\text { de carbonatos e bicarbonatos de amônia diluídos em água, reforçada com o } \\
\text { sal ADTA dissolvido na solução em menores proporções. Recomenda-se } \\
\text { testar anteriormente todos os produtos. } \\
\text { Limpeza mecânica: uso de métodos abrasivos em superfícies ainda coesas, } \\
\text { sem desagregação superficial, nas áreas do material onde os métodos }\end{array}$ \\
\hline
\end{tabular}

6 Esse tipo de dano foi observado em estruturas com tijolos dos séculos XVIII e XIX em Igarassu, PE, dentro de fazendas, estruturas com chaminés e na Feitoria de Cristóvão Jaques. Outros danos em tijolos in situ observados em ruínas encontradas em Pernambuco (Sesmaria Jaguaribe, Abreu e Lima, PE; Igarassu, PE) incluem a incrustação por valvas de moluscos (Ostrea sp), algas e ação de cupins em nichos com madeiramento de estruturas de parede. 


\begin{tabular}{|c|c|}
\hline & $\begin{array}{l}\text { anteriores não foram eficazes; utilização do micro jateamento de areia } \\
\text { (microesferas de vidro, pó de mármore, gesso, pó de quartzo) para retirar as } \\
\text { sujidades (tintas, crosta negra e manchas), com equipamento importado; uso } \\
\text { de micro abrasador (brocas dentárias) que é um método de limpeza abrasivo } \\
\text { limitado, para uso em pequenas superfícies; limpeza com bisturi em pequenas } \\
\text { áreas; limpeza a laser com pistola de jatos de raio laser para remover as } \\
\text { sujidades antes não removidas. }\end{array}$ \\
\hline Sais solúveis & $\begin{array}{l}\text { Constituem uma das principais causas de alterações nos produtos cerâmicos e } \\
\text { podem se manifestar de diversas formas. Alguns são invisíveis a olho nu. } \\
\text { Assim, o tratamento é sensível e repetitivo, com uso de água desmineralizada } \\
\text { e deionizada, empregados até a dissolução dos sais em procedimentos } \\
\text { sucessivos de lavagem. }\end{array}$ \\
\hline $\begin{array}{l}\text { Reconstituição ou } \\
\text { montagem }\end{array}$ & $\begin{array}{l}\text { Uso de próteses: de rocha ou argila artificial (pó de tijolo com } \\
\text { aglomerante e consolidante) com cor e textura semelhantes às do } \\
\text { material em reconstituição. Podem ser aderidas com cola ou resina } \\
\text { por encaixe com pinos metálicos em aço inox ou latão ou } \\
\text { preenchimento com resinas entonadas nas áreas de encaixe (colas } \\
\text { epóxicas, resinas de poliéster, poliuretano e acrílicas oferecem boa } \\
\text { adesão, durabilidade, baixa retração, elasticidade e rigidez). } \\
\text { Uso de argamassas: são usadas no preenchimento de fissuras em } \\
\text { pedras de cantaria. Produzidas com cal hidráulica como aglomerante, } \\
\text { podem ter vários agregantes, conforme a granulometria do material a } \\
\text { ser reconstruído. Podem ser acrescidos fungicidas, filtros de UV, } \\
\text { pigmentos inorgânicos quimicamente estáveis, como terras e óxidos } \\
\text { metálicos. O uso de cimento pode resultar na formação de sais } \\
\text { solúveis. } \\
\text { Uso de polímeros: pastas de resina de poliéster, epóxicas e acrílicas } \\
\text { são mais usuais, com agregantes que variam conforme a cor e a } \\
\text { textura do material, para a devida reintegração cromática e da } \\
\text { textura, conforme a linha de restauro adotada, podendo ser de talco, } \\
\text { dióxido de zinco, pó de mármore, microesferas de vidro, óxidos e } \\
\text { terras inertes. A agregação de produtos filtrantes (de raios UV) } \\
\text { depende de testes preliminares. No uso de pastas de cola e adesivos } \\
\text { deve-se atentar aos problemas citados das pastas reconstrutivas ou } \\
\text { reconstruidoras. Em laboratório são recomendáveis procedimentos } \\
\text { reversíveis de recuperação da coesão do produto cerâmico por meio } \\
\text { da colagem (colas reversíveis preferencialmente e não contaminantes) } \\
\text { de partes passíveis de montagem. }\end{array}$ \\
\hline Consolidação & $\begin{array}{l}\text { Processo de impregnação de consolidantes para melhorar e aumentar a } \\
\text { coesão do material alterado, para maior resistência aos processos } \\
\text { degradativos. Podem ser usados produtos orgânicos (polímeros, mais } \\
\text { elásticos e maior adesão) e inorgânicos (menos elásticos e mais duráveis). Os } \\
\text { consolidantes não devem formar subprodutos deteriorantes; devem ser } \\
\text { absorvidos uniformemente pelo material; podem ter profundidade de } \\
\text { penetração controlável, conforme as características do material, pela fluidez } \\
\text { do consolidante; devem ter o coeficiente de dilatação térmica próximo do da } \\
\text { rocha a ser consolidada; caso sejam repelentes à água, não devem tornar a } \\
\text { rocha impermeável totalmente; devem manter a aparência externa da rocha, } \\
\text { sem brilhos ou modificação da coloração. Os consolidantes são aplicados com } \\
\text { pincéis, escovas, pulverização, impregnação à vácuo em autoclaves } \\
\text { específicas. A consolidação em laboratório implica da infiltração de uma } \\
\text { substância sólida ou líquida dissolvidas em um solvente que poderão } \\
\text { impregnar o produto cerâmico, desde a sua superfície até o seu interior. }\end{array}$ \\
\hline
\end{tabular}




\begin{tabular}{|c|c|}
\hline & $\begin{array}{l}\text { Tipos de consolidantes por tipos de materiais: a) arenitos e cerâmicas: } \\
\text { consolidantes a base de silicato de etila; alquil-alcoxisilano; mistura de silicato } \\
\text { de etila e alquil-alcoxisilano; b) arenitos, calcários e mármores: uso de alquil- } \\
\text { aril-polisiolaxano; mistura de resina acrílica e silicone; c) mármores e calcários } \\
\text { compactos: uso de resina acrílica; d) rochas calcárias: uso de hidróxido de } \\
\text { bário ou hidróxido de cálcio. }\end{array}$ \\
\hline $\begin{array}{l}\text { Proteção/ } \\
\text { Conservação } \\
\text { preventiva }\end{array}$ & $\begin{array}{l}\text { Uso de produtos químicos ou eliminação dos agentes de degradação dos } \\
\text { materiais (rochas, tijolos e telhas). Os trabalhos de conservação possuem } \\
\text { vida útil limitada e demandam inspeçães e manutenções periódicas. } \\
\text { Para proteção superficial: evitar poluição, condensação de umidade química } \\
\text { e mecânica, ação da chuva (exceto em casos de capilaridade) utilizam-se } \\
\text { produtos inertes, que não formem produtos degradadores do material, com } \\
\text { boa estabilidade química, boa estabilidade contra raios UV, boa } \\
\text { permeabilidade de vapores de água, mínima mudança das propriedades } \\
\text { óticas e cromáticas do material. São recomendados para todos os tipos de } \\
\text { materiais as misturas de resinas acrílicas e silicones ou o alquil-aril- } \\
\text { polisiolaxano. Os mármores e materiais de baixa porosidade podem ser } \\
\text { protegidos com resinas acrílicas. } \\
\text { Para evitar mudanças cromáticas do material, adiciona-se ao agente protetor } \\
\text { produtos filtrantes de raios UV indicados. } \\
\text { Proteção contra umidade: é usada in situ e constitui-se de métodos de } \\
\text { eliminação das fontes de umidade. } \\
\text { Uso de barreira física: contra a umidade por capilaridade e formação de sais } \\
\text { solúveis. A alvenaria é cortada e aplicada resina de poliéster formando uma } \\
\text { barreira física ao longo da alvenaria. } \\
\text { Controle climático interno: para evitar condensação de água e poluentes do ar } \\
\text { Vala de ventilação: criação de vala em torno da fundação para a evaporação } \\
\text { da água antes que esta penetre na parede. } \\
\text { Vala de ventilação com enchimento: criar vala ao redor das fundações, } \\
\text { preenchida com material drenante, afastando a umidade das paredes do } \\
\text { edifício. } \\
\text { Proteções diversas: beirais, drenos, calhas, conserto de tubulações de água, } \\
\text { uso de impermeabilizantes. } \\
\text { Manter o ambiente de conservação do objeto cerâmico, com temperatura e } \\
\text { umidade mais recomendados (e sustentáveis), verificação das embalagens e } \\
\text { forma de armazenagem. }\end{array}$ \\
\hline Acondicionamento & $\begin{array}{l}\text { Os materiais avulsos, coletados in situ devem ser acondicionados, } \\
\text { verificando-se preliminarmente as alterações e danos que já possuam e as } \\
\text { formas de estabilização de processos degradativos degenerativos. A guarda } \\
\text { em RT com controle de temperatura e umidade relativa, bem como } \\
\text { recipientes adequados para cada tipo de material pode propiciar a } \\
\text { preservação mais eficaz. Entretanto, as inspeções e manutenções periódicas } \\
\text { do ambiente, de etiquetas, e dos recipientes e estantes de guarda. A eficácia } \\
\text { dos métodos de acondicionamento depende do sistema de gerenciamento da } \\
\text { guarda e dos riscos do material em reserva ou museu. }\end{array}$ \\
\hline
\end{tabular}

Fonte: adaptado de Almeida (2000) e Moliner (2009).

A avaliação sobre a natureza da matéria que compõe o produto cerâmico e as suas patologias, para fins de instauração mais adequada de uma proposta de intervenção em conservação e restauro, deve considerar determinados estudos preliminares (Moliner, 2009). São eles: a) históricos; b) geológicos e edafológicos (desde o início da escavação, quando possível); c) climático (na peça e no ambiente); d) análise físico-química (pela obtenção de amostras). 
Sobre as características da massa cerâmica, podem ser solicitadas algumas análises (Moliner, 2009), conforme as necessidades das intervenções de conservação e restauro (Quadro 5).

Quadro 5. Análises para a avaliação de uma proposta de intervenção e estudo arqueológico em produtos cerâmicos - tijolos.

\section{Análises para a caracterização de produtos cerâmicos (Moliner, 2009), adaptado para tijolos}

1 - Identificação da natureza da massa cerâmica ou argila (barro natural de tijolo)

\begin{tabular}{|c|c|}
\hline Composição química & $\begin{array}{l}\text { Absorção atômica, Espectrofotometria, } \\
\text { Fluorescência de Raios-X, Microssonda } \\
\text { eletrônica }\end{array}$ \\
\hline Composição mineralógica & Difração de Raios X \\
\hline $\begin{array}{l}2 \text { - Aspectos sobre a porosidade da } \\
\text { massa cerâmica }\end{array}$ & Métodos e técnicas \\
\hline Porosidade & $\begin{array}{l}\text { Absorção de água; porosimetria por } \\
\text { mercúrio }\end{array}$ \\
\hline 3 - Aspectos da cronologia do objeto & Métodos e técnicas \\
\hline Datação & Termoluminescência \\
\hline $\begin{array}{l}\text { 4- Aspectos relativos ao processo da } \\
\text { queima }\end{array}$ & Métodos e técnicas \\
\hline Condições de cocção & Dilatrometria; Análise térmica TG e DTA \\
\hline $\begin{array}{l}5 \text { - Aspectos relativos à cor após a } \\
\text { queima }\end{array}$ & Métodos e técnicas \\
\hline ( & $\begin{array}{l}\text { Tabela de Munsell; Colorimetria, } \\
\text { colorímetro digital }\end{array}$ \\
\hline $\begin{array}{l}6 \text { - Identificação das alterações } \\
\text { químicas }\end{array}$ & Métodos e técnicas \\
\hline No produto cerâmico & $\begin{array}{l}\text { Espectrofotometria de plasma, Absorção } \\
\text { atômica, Fluorescência de Raios-X, } \\
\text { Análise Térmica TG e DTA }\end{array}$ \\
\hline $\begin{array}{l}\text { 7-Identificação das alterações } \\
\text { microbiológicas }\end{array}$ & Métodos e técnicas \\
\hline Contaminação microbiológica & $\begin{array}{l}\text { Análise Térmica TG e DTA, Microscopia } \\
\text { óptica e eletrônica (MEV - Microscopia } \\
\text { eletrônica de varredura) }\end{array}$ \\
\hline
\end{tabular}

Fonte: Traduzido e adaptado de Moliner (2009, p. 66) para ser considerado nas análises de tijolos.

Na proposição de Najjar e Duarte (2002), no âmbito de projetos de restauração de bens imóveis regidos pela interação entre arqueólogos, historiadores e arquitetos, estabelece inicialmente que a pesquisa arqueológica produz resultados exclusivos para a restauração, onde o arqueólogo está atrelado ao trabalho do arquiteto, fornecendo-lhe dados imediatos. A troca de informações entre arqueólogos e arquitetos nos projetos de restauração e conservação de monumentos é fundamental. Entretanto, é imprescindível, que o arqueólogo 
esteja comprometido com a produção de conhecimento sobre o monumento ou conjunto de edificações históricas sobre as quais implantou a sua pesquisa, pois para o Poder Público, o bem é preservado de formas mais adequadas quando este é conhecido. A arqueologia está presente nas ações de preservação do patrimônio cultural, pois está prevista na Carta de Veneza e no Decreto Lei ${ }^{\circ} 25 / 37$ (Cury, 2004), conforme explanado por Najjar e Duarte (2002).

\section{O exemplo da coleção de tijolos do Programa Monumenta - Recife}

Conservação é uma disciplina sistematizada nos processos de investigação, resgate e gerenciamento de coleções arqueológicas (Froner, 2007). Nesta pesquisa, Oliveira (2017) utilizou uma ficha de danos para registrar o estado de conservação da coleção de tijolos do Programa Monumenta - Recife, com o objetivo de apoiar o estudo dos atributos superficiais, formais e tecnológicos dos tijolos arqueológicos, procurando ampliar o seu potencial de análise e interpretação do universo cultural do qual provêm, diminuindo o potencial de risco da coleção em estudo em relação ao manuseio e posterior acondicionamento.

Os tijolos resgatados no Programa Monumenta Recife entre 2006 e 2007 apresentaram características peculiares de conservação, desde a argamassa ainda presente a sujidades de asfalto e quebras recentes, assim como superfícies pulverulentas pela degradação superficial decorrente de atritos entre os tijolos e seus fragmentos.

Quanto ao estado de conservação dos tijolos íntegros, $100 \%$ dos mesmos encontravam-se completos, com mais de $75 \%$ da sua estrutura e sempre apresentaram as três dimensões comprimento, largura e altura - mensuráveis. No total de 268 tijolos analisados, 47 (17,54\%) estão íntegros e 221 (82,46\%) são fragmentos, com ou sem sinais de uso.

Alguns fragmentos de tijolos (MM1779.1, MM1913.1, MM874.4) apresentaram argamassa em área de quebra, indicando o seu uso como meio tijolo. Esse tipo de artefato é reaproveitado e fraturado de acordo com as necessidades da construção (os meios tijolos ou brickbatcitados por Clarke, 1868). O meio tijolo é útil nas alvenarias, acabamentos e para fechar aberturas.

Quanto à sugestão de intervenção, recomendou-se a estabilização para $100 \%$ dos tijolos íntegros, considerando a sua fragilidade e estado de decomposição superficial que afeta a amostra em menor ou maior grau. O contato prolongado entre tijolos - como no caso de outros tipos de vestígios arqueológicos - é substancialmente danoso, pois pode prejudicar análises futuras e contaminar as superfícies de outros artefatos que estão em contato.

Do mesmo modo, foi sugerido um processo de intervenção por limpeza mecânica, com mínima erosão. Esta limpeza minimamente interventiva e predominantemente investigativa manteve, por exemplo, toda e qualquer reminiscência de argamassa aderida aos tijolos. Análises de fluorescência da argila podem ser prejudicadas pela presença e impregnação de cálcio da argamassa no tijolo ou outros compostos químicos presentes no sítio arqueológico. Desse modo, foram limpas com pincéis ou remoção mecânica com estaca de madeira as superfícies menos impregnadas em áreas de $0,5 \mathrm{~cm}^{2}$, exclusivamente para tomadas do instrumento portátil de fluorescência. 
Como exemplo, no caso exclusivo do tijolo MM2064 (Figura 1), formado por dois fragmentos (MM2064.1 e MM2064.2), recomendou-se a sua consolidação seguida de colagem, conquanto tenham sido coletadas e reservadas amostras e subamostras internas (para fluorescência, difratometria e coleta de pólens e micro vestígios de carvão e biológicos em geral) antes desse procedimento.

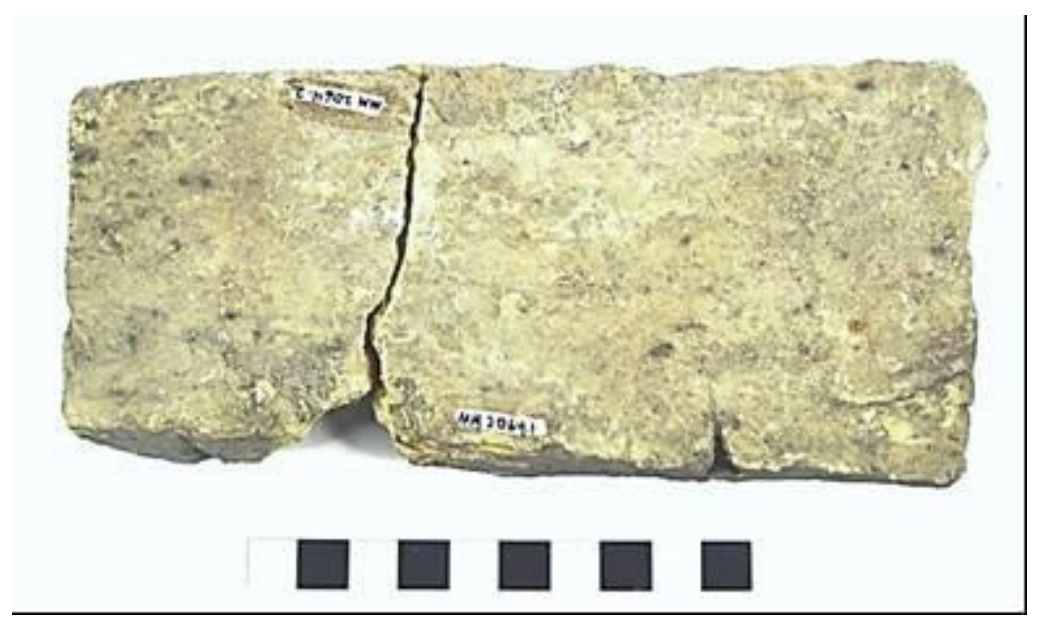

Figura 1. Aspecto do tijolo MM2064.1/MM2064.2, formado por dois fragmentos (escala $10 \mathrm{~cm}$ ). (Fonte: Maria Oliveira, inventário geral dos tijolos Monumenta Lacor, DARQ/UFPE, 2017).

A mensuração e peso desse tijolo foi possível mediante uma reconstituição temporária dos fragmentos. Após as análises, os dois fragmentos foram acondicionados em recipientes individuais.

A ficha de danos empregada contemplou alguns dos aspectos referentes das modificações tafonômicas e eventualmente relacionadas com a caracterização do estado de conservação dos tijolos. Nesse caso, foram registradas algumas características preliminarmente estabelecidas, conforme adaptações de Almeida (2000), Moliner (2009) e Vogel (2015).

Foram observadas e registradas algumas patologias de superfície previamente estabelecidas (Gráfico 1): a) presença de sais; b) quebras; c) rachaduras e fissuras; d) presença de óxidos; e) manchas diversas; f) sinais de deformação, relacionados ou não à queima; g) marcas de arranhões ou escoriações e de atrito na superfície cerâmica; h) presença de carvão ou mancha de carvão; i) presença de fungos; j) presença de sinais da ação de cupins; k) presença de impressões de vegetais deixadas antes da queima; I) presença de mancha vítrea. 0 gráfico abaixo apresenta as quantidades dessas alterações observadas nos tijolos íntegros (17,54\% da coleção). 
Gráfico 1. Patologias na superfície dos tijolos do Programa Monumenta Recife antes, durante e após a queima $(n=47)$

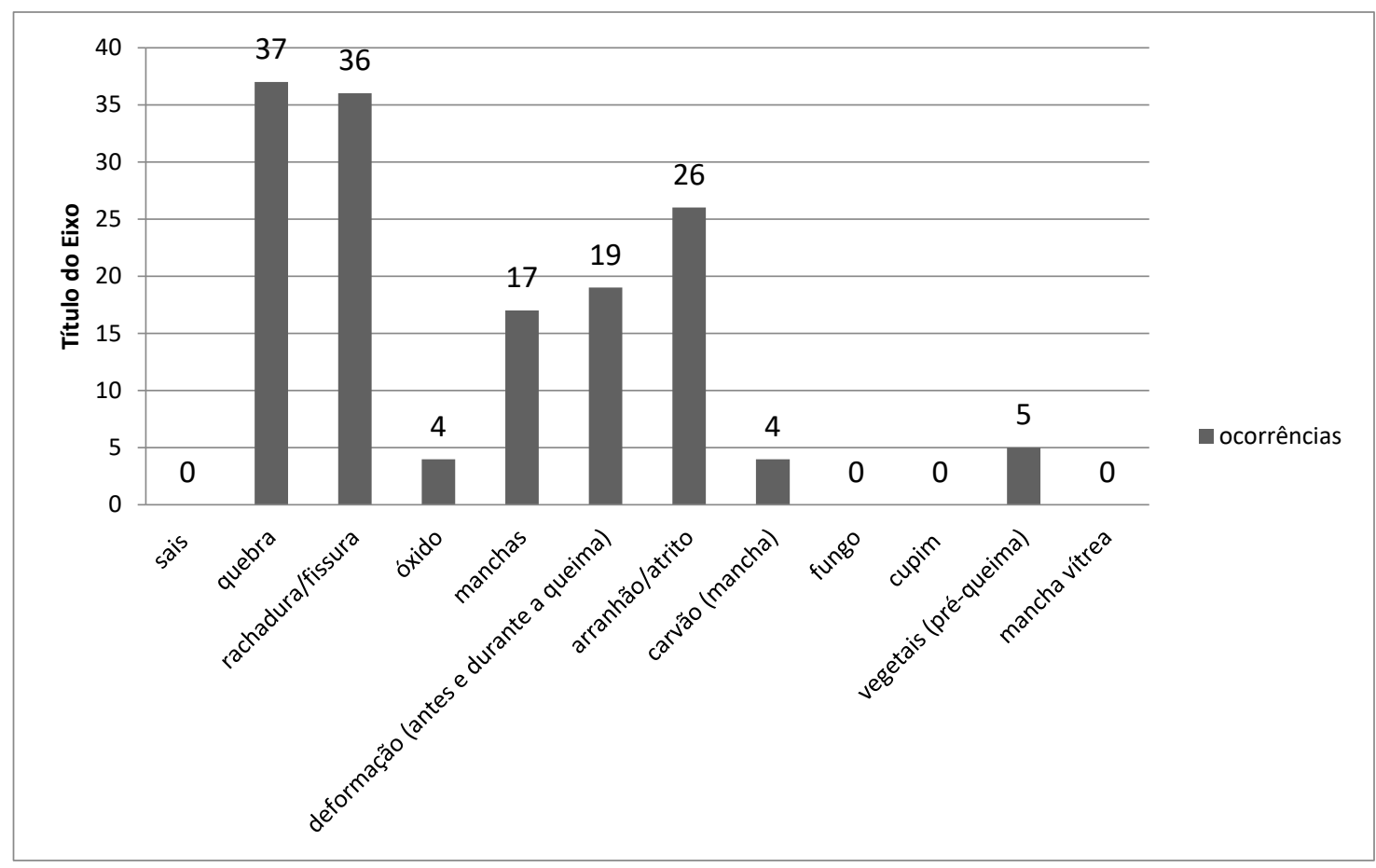

Conforme as observações sobre as alterações tafonômicas na coleção, não foram observadas marcas de sais, fungos, cupins ou mancha vítrea (que indica baixa queima da argila). Foram registradas 37 peças com quebras (em arestas ou faces); 36 com rachaduras e fissuras, possivelmente ocasionadas durante a secagem e/ou a queima em forno; 4 peças com concentrações de óxidos, em forma de nódulos ou concreções na massa de argila; 17 manchas de diversos materiais, como tinta ou óleo; 19 peças com algum sinal de deformação, possivelmente associada à manufatura (queima elevada, por exemplo); 26 peças com algum sinal de atrição ou corte, possivelmente associadas a antigas intervenções no sítio com uso de instrumentos de escavação; 4 tijolos com sinais de carvão, associadas a uma segunda queima não vinculada ao processo de manufatura; e 5 tijolos com sinais de vegetais - marcas negativas de caules - inseridos na massa cerâmica, indicando elementos intrusivos do ambiente dentro do processo de manufatura do artefato.

Algumas dessas características estão associadas aos atributos tecnológicos envolvidos com a manufatura dos tijolos e outras aos processos tafonômicos relacionados à própria formação do depósito arqueológico.

Em se considerando a existência dessas alterações no momento do estudo, foram feitas algumas sugestões de intervenções. O Gráfico 2 apresenta o quantitativo dos processos de intervenção, não exclusivos, sugeridos em um conjunto de 47 tijolos íntegros do Programa Monumenta, Recife. 
Gráfico 2. Número de procedimentos invasivos sugeridos em 47 tijolos íntegros (Monumenta)

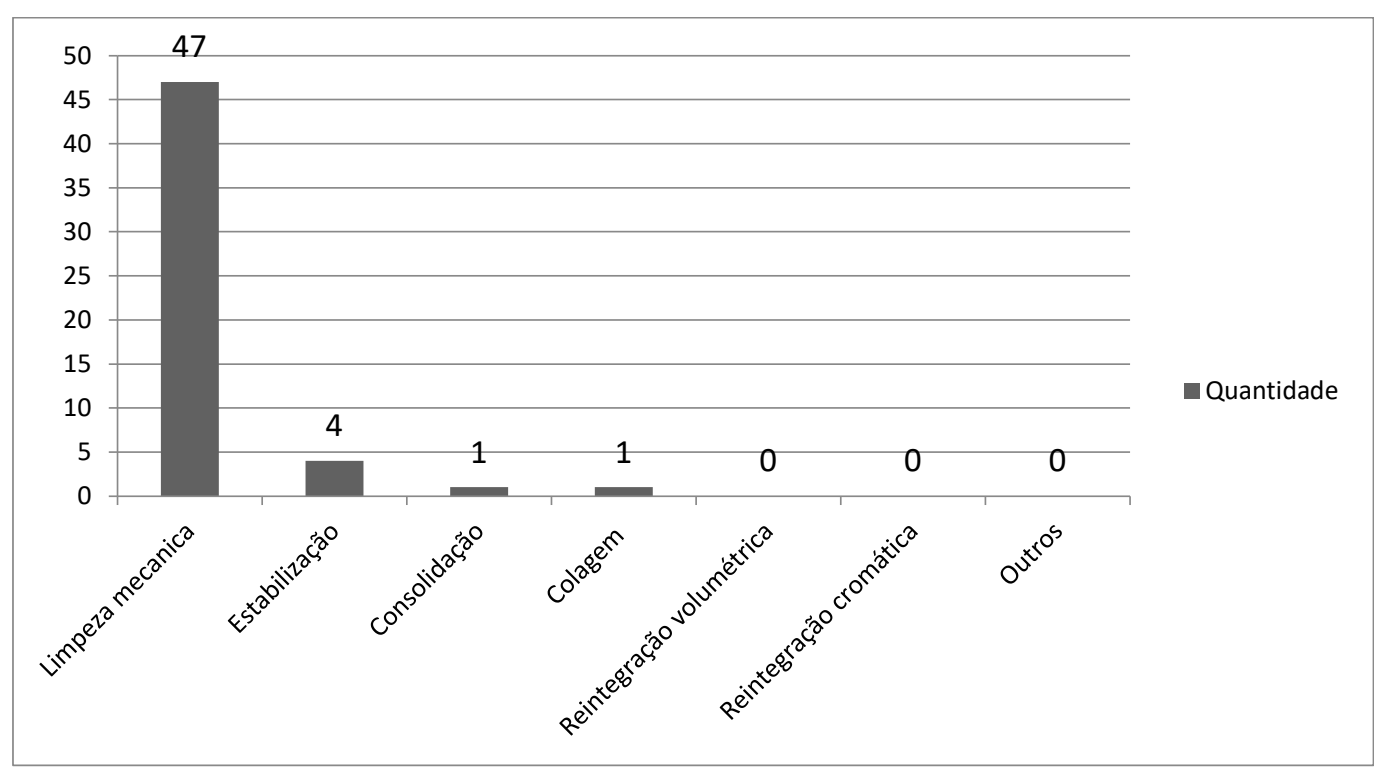

Sobre as sugestões para o acondicionamento dos tijolos e a sua ambiência, para a coleção como um todo (íntegros e fragmentos), foi sugerida a troca das embalagens e a revisão do tipo de recipiente, no caso das caixas.

Também se recomenda, em uma ação de conservação imediata, o acondicionamento individual dos tijolos em recipientes ou gavetas, com superfícies neutras isolantes entre e sob eles, dentro de caixas ou gavetas de estantes basculantes, para que não continuem ocorrendo ou sejam minimizados os danos por atrito entre as suas superfícies (aranhões e fraturas em arestas, bases, faces e lados). Esse acondicionamento (Figura 2) foi feito em toda a coleção de tijolos.

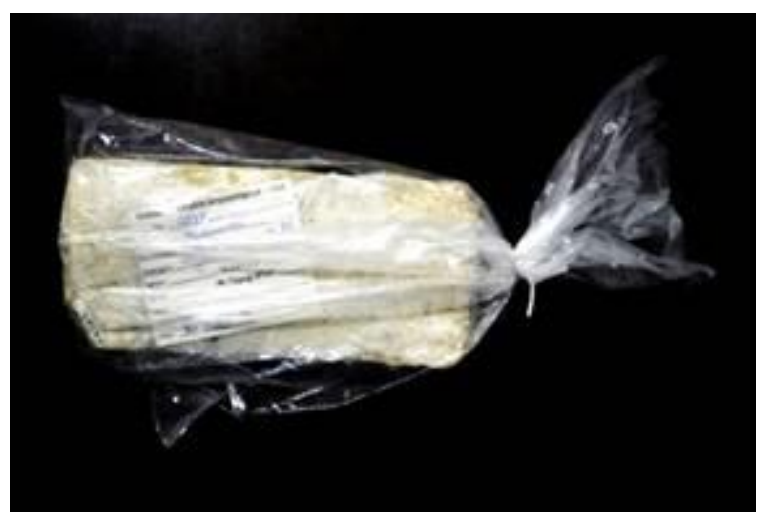

A

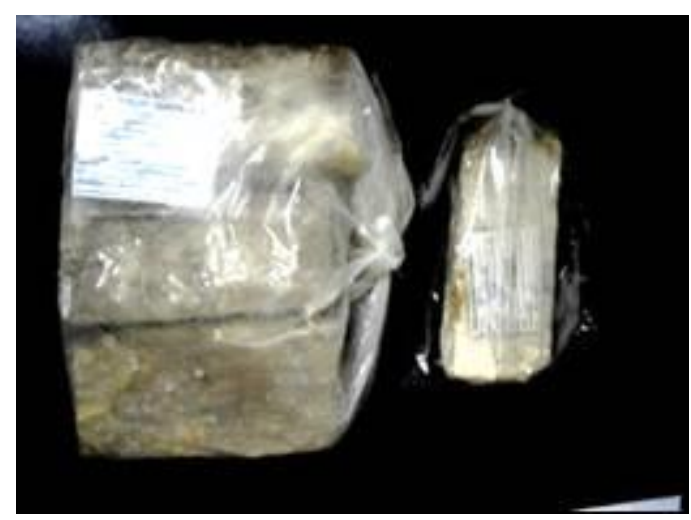

B

Figura 2. Formas de acondicionamento individual e em conjunto dos tijolos da coleção Programa Monumenta Recife: A. Tijolo embalado individualmente e com etiqueta também acondicionada; $B$. Tijolos embalados em conjunto, após serem embalados individualmente. A camada de plástico da embalagem impede o contato abrasivo direto entre os artefatos. $\mathrm{O}$ acondicionamento em prateleiras do tipo gaveta ou lado a lado é recomendável para evitar-se o empilhamento dos artefatos. Fonte: Maria Oliveira, Lacor, Darq-UFPE, 2017. 
As etiquetas antigas podem ser refeitas e anexadas juntas no recipiente de cada tijolo, visto que conjuntos de tijolos embalados em um mesmo recipiente plástico possuem uma só etiqueta de identificação. As etiquetas antigas perfazem documentação arqueológica e devem ser preservadas, sempre junto com as novas. Observou-se que o contato entre tijolos é sempre prejudicial, como também para outros materiais arqueológicos e para a sua conservação.

A coleção de tijolos estava acondicionada em local com umidade relativa e temperatura ambiente. Não foi verificada qualquer modificação tafonômica macroscópica resultante de bioturbação ou ação das águas ou temperatura. O material é de alta resistência e ofereceu excelente condição para a sua preservação em RT. Entretanto, recomenda-se, a adequação de recipientes e espaços de guarda conforme o peso total dos materiais, considerando que somente os tijolos íntegros da coleção $(17,40 \%)$ pesam $47.077 \mathrm{~g}$ e que o contato direto entre eles é danoso para o seu estudo morfológico.

O estudo dos tijolos provenientes de um sítio arqueológico, como o do bairro de Recife, auxilia na compreensão da tecnologia, uso do espaço e da evolução urbana que o caracterizam e para estabelecer o seu lugar e temporalidade em um contexto regional. Busca uma interpretação do local a partir de uma revisão compreensível da história que está preservada no tijolo arqueológico. Nesse sentido, a caracterização morfológica, tecnológica e funcional dos tijolos pode ser empregada para compreender as formas de habitar, diagnosticar importações e mapear as características da produção de tijolos em uma dada região.

Segundo Oliveira (2017), muito embora possam ser obtidas datas aproximadas e relativas sobre os tijolos e argamassas, os arqueólogos devem levar em consideração que esse tipo de artefato tem sido, ao longo da história, reciclado e reutilizado. A observação das mudanças nas alvenarias é útil para determinar a presença de adições e remodelações de áreas de antigas estruturas com tijolos mais novos ou de novas estruturas com tijolos bem mais antigos, reutilizados (Vogel, 2015). A data de um tijolo nem sempre corresponde a data de uma construção e no caso dos tijolos do Recife, tijolos com formatos específicos podem corresponder a exemplares oriundos não somente da Holanda, mas de outras localidades da Europa e de épocas diversas, de produções recém exportadas e de tijolos reaproveitados de longa data e que possuem traços desse reuso, tanto quanto de incêndios, demolições, entre outros eventos.

\section{Referências}

ALMEIDA, F. F. N. (coord) Manual de Conservação de Cantarias. $5^{\text {a }}$ SR-IPHAN-Grupo Tarefa do Programa Monumenta - UNESCO - Minc, 2000.

BOITO, C. Os Restauradores. Cotia/SP: Ateliê Editorial, 2003.

BRANDI, C. Teoria da Restauração. Cotia/SP: Ateliê Editorial, 2003.

BRASIL, Ministério da Cultura, Programa Monumenta. Sítios históricos e conjuntos urbanos de monumentos nacionais: norte, nordeste e centro-oeste. Brasília: Ministério da Cultura/Programa Monumenta, 2005, (Programa Monumenta, v.1; cadernos técnicos 3). 
CALDEIRA, C. C. Conservação preventiva: histórico. R.CPC, São Paulo, v.1, n.1, p.91-102, nov. 2005/abr. 2006.

CLARKE, H. On the manufature of bricks and tiles in Holland. In. DOBSON, E.A rudimentary treatise on the manufacture of bricks and tiles containing an outline of the principles of brickmaking. 4 ed. London: Virtue and Co.Cap.2, p.47-48, 1868.

CRONYN, J. M. The elements of Archaeological Conservation. London: Routledge-Taylor \& Francis Group, 1990.

CURY, I. (org.) Cartas Patrimoniais. 3. ed. Rio de Janeiro: Iphan, Rio de Janeiro, 2004.

DUARTE JUNIOR, R. Programa Monumenta: uma experiência em preservação urbana no Brasil. Revista CPC, São Paulo, n. 10, p.49-88, mai. /out. 2010.

FRANÇA, E.; BRANDÃO FILHO, J. O. de C. Auditoria Cultural: Intervenções em Bens Culturais Afetados por Proteção Legal. Recife: Tribunal de Contas do Estado de Pernambuco, 2014.

FRONER, Y. A. Conservação preventiva e patrimônio arqueológico: ética, conceitos e critérios. Revista do Museu de Arqueologia e Etnologia da USP, n. 1, v.5, p. 291-301, 1995.

FRONER, Y. A. Materiais para conservação em museus. In. Museologia: roteiros práticos - conservação de coleções. São Paulo: Edusp, 2005

FRONER, Y. A. Memória e Preservação: a construção epistemológica da Ciência da Conservação. Memória \& Informação 2007. Rio de Janeiro: Fundação Casa de Rui Barbosa. P.1- 25, 2007. Disponível em: $\quad$ http://www.casaruibarbosa.gov.br/dados/DOC/palestras/memo_info/mi_2007/FCRB_MI_ Memoria_e_Preservacao__A_construcao_epistemologica_da_Ciencia_da_Conservacao.pdf $>$. Acesso em: 20 ago. 2015.

FRONER, Y. A. Reserva Técnica: bases para um planejamento seguro. II Forum de Profissionais de Reserva Técnica de Museus. COREM. São Paulo, 2001.

GHETTI, N. C. Conservação Integrada e Conservação Preventiva: uma abordagem para a preservação e salvaguarda do patrimônio cultural de Ciência e Tecnologia. In: /l Seminário de Gestão do Patrimônio Cultural de Ciência e Tecnologia, Recife, 2013.

GHETTI, N. C. Saber cuidar: a Conservação Arqueológica em perspectiva para a preservação, salvaguarda e a valorização do acervo arqueológico. In: Il Congreso de Arqueología de la Cuenca del Plata, San José de Mayo. 2014.

GHETTI, N. C. Saber cuidar: a conservação para valorizar e preservar o acervo arqueológico. In: Anais do XV Congresso da Sociedade de Arqueologia Brasileira. Belém: XV Congresso da Sociedade de Arqueologia Brasileira, v. 1, p. 18, 2009.

GHETTI, N. C.; NAJJAR, R; RIEHL, C. A. S. Preservação e valorização de acervos: a investigação físicoquímica na sistemática da conservação arqueológica. Nós da Arqueologia. RJ: IPHAN, 2009. 
HIRATA, E.; FRONER, Y-A. Gerenciamento e controle de coleções em reserva técnica. Revista do Museu de Arqueologia e Etnologia da USP, n. 1, v. 7, p 193-198, 1997.

LE GOFF, J. Memória/História. In. Enciclopedia Enaudi. Portugal: Imprensa Nacional/Casa da Moeda, v.1, p. 95-106, 1982.

LEAL, A. P. da R. Arqueologia, Museologia e Conservação: documentação e gerenciamento da coleção proveniente do sítio Santa Bárbara, Pelotas, RS. Dissertação apresentada ao Programa de pósgraduação em Antropologia (área de concentração Arqueologia). Pelotas: UFPEL, 2014.

LIRA, F. B. Teoria da Restauração I. Curso de Gestão e Prática de Obras de Conservação e Restauro do Patrimônio Cultural, 15 ed.p.1-18, Aula 1, 2015.

MATERO, F. G. Heritage, Conservation, and Archaeology: an introduction. AlA Site Preservation Program. USA: Archaeological Institute of America, p.1-5, [2015]. Disponível em: <https://www.archaeological.org/pdfs/Matero.pdf>. Acesso em: 18 ago 2015.

MATOS, M. X. G. de. Análise de estruturas em alvenaria: modelo para análise e identificação dos processos construtivos e das etapas de execução de uma edificação de valor histórico/cultural. 2009. Dissertação (Mestrado em Arqueologia). Programa de Pós-Graduação em Arqueologia, Universidade Federal de Pernambuco, Recife, 2009.

MENDES, M. (org.) Conservação: Conceitos e Práticas. Rio de Janeiro: Editora da UFRJ, 2001.

MOLINER, B. C. La Conservación y restauración de objetos cerámicos arqueológicos. Madri: Grupo Editorial Tecnos, 2009.

MORRIS, W. In. Historical and Philosophical Issues in the Conservation Cultural Heritage. Los Angeles: GCl, p. 268-274, 1996.

NAJJAR, R.; DUARTE, M. C. C. Manual de Arqueologia Histórica em projetos de restauração. Brasília: IPHAN/Programa Monumenta/BID/Deprot. 2002.

OLIVEIRA, M. A. da S. Estudo da coleção de tijolos do Programa Monumenta, Bairro do Recife - PE, sob a perspectiva da arqueologia histórica e subsídios da conservação. Dissertação (Mestrado em Arqueologia). Programa de Pós-Graduação de Arqueologia, Universidade Federal de Pernambuco, 2017. PESSIS, A-M.; MARTIN, G.; OLIVEIRA, C. A. (coords.) Processo de urbanização do Bairro do Recife nos séculos XVII e XVIII. Recife: Programa de Pós-Graduação de Arqueologia/Departamento de História/UFPE/Programa Monumenta-BID/URB-Recife, 2006 (Projeto de Pesquisa).

RIEGL, A. El culto moderno a los monumentos. Madri: La Balsa de la Medusa: Editora Visor, 1999.

RUFINO, E. Arqueologia no Bairro do Recife/PE. Monografia. Recife: UNICAP. Curso de Especialização em Patrimônio Histórico: Preservação e Educação. 2013.

RUSKIN, J. The seven lamps of Architecture. New York: Dover Publications, 1989. 
TINOCO, J. E. L. Anotações sobre critérios de intervenção de conservação e restauração em edificações de valor cultural. Curso de Gestão e Prática de Obras de Conservação e Restauro do Patrimônio Cultural, 15 ed. Aula 3, Teoria do Restauro III, 2015.

VASCONCELOS, M. L. C. O conservador na gestão de acervos arqueológicos: um estudo de caso do sítio Guarani EM-03 Totó (RS-Brasil). Monografia (TCC do curso de Conservação e Restauração de Bens Culturais Móveis). Pelotas: Departamento de Museologia e Conservação e Restauro, Instituto de Ciências Humanas da Universidade Federal de Pelotas, 2011.

VELOSA, G. História da Conservação e Restauro e Arqueologia. Portugal: Departamento de Gestão do Território do Instituto de Tomar, 2008. Disponível em: < http://5cidade.filis.worldpress.com/2008/04/historia-da-conservaçao-e-restauro.pdf >. Acesso em: 10 dez. 2014.

VIOLLET-LE-DUC, E. E. Restauração. Cotia/SP: Ateliê Editorial, 2000.

VOGEL, M. N. Up Against the Wall: in Archaeological Field Guide to Bricks in Western New York. Buffalo Architecture and History. 2015. Disponível em <http://www.buffaloah.com/a/DCTNRY/mat/brk/vogel/>. Acesso em 10 dez 2015. 